\title{
Education and civic engagement: A comparative study of the benefits of post-compulsory education in England and Germany
}

\author{
Emma Salter \\ e.j.salter@sussex.ac.uk

Angelika Kuemmerling
Rod Bond
Ricardo Sabates

(Received September 2015

\author{
University of Sussex, UK \\ Institut Arbeit und Qualifikation, University of Duisburg-Essen, Germany \\ University of Sussex, UK \\ University of Cambridge, UK
}

Revised August 2016) http://dx.doi.org/10.14301/llcs.v8i2.372

\section{Abstract}

This paper examines the role of different types of post-compulsory education in determining civic engagement (political interest and election participation) in England and Germany. The educational systems of England and Germany provide ideal comparators for investigating the social benefits of education, in particular those that accrue from vocational education. The paper uses two longitudinal panel surveys, the British Household Panel Survey and the German Socio-Economic Panel for empirical purposes. Contrary to our expectations, our findings revealed few differences between the two countries: the level of political interest is the same for youth who had a vocational degree as those without any further qualifications, in both England and Germany. Similarly, greater levels of interest in politics were observed in adulthood for youth who had achieved academic qualifications in both countries. Likewise voting behaviour in particular was associated with the achievement of academic qualifications in Germany and to some extent with the achievement of mixed vocational and academic qualifications in England.

\section{Keywords}

Education, civic engagement, voting, politics, comparative, England, Germany

\section{Introduction}

A free and democratic state is reliant on the active participation of its citizens. By participating in elections and other civic engagement citizens are able to influence politics; the involvement of all citizens in democratic processes and the extent to which they are enabled to be involved are crucial for ensuring that all citizens have an equal chance of participation and political integration (Weßels, 2008). Individuals with higher levels of political interest are in general more likely to vote (Prior, 2010), therefore the converse follows: in a society of citizens with low or no interest in politics, voting levels would drop; a situation that is anathema to a democracy (Brennan, Durazzi \& Sene, 2013). Thus, it is important for a society to understand the mechanisms that contribute to individuals' propensity for civic engagement.

Since Aristotle's writing in The Politics and the Constitution of Athens (Aristotle translated by Everson, 1996) about the importance of education in the creation of a democratic society, there have been debates around the role of education in this process (Grenier \& Wright, 2006; Lochner, 2011). Previous research has shown that higher levels of education correlate positively with political interest 
and political participation (OECD, 2014; Lochner, 2011). But those studies tend to focus on general (academic) education or years of education (Ogg, 2006; OECD, 2014; de Walque, 2007); much less research has addressed differences depending on the type of education. While some researchers have examined the role of vocational education and training in the formation of civic engagement (Sabates et al., 2010), whether vocational education and training has a similar or different role to academic education in forming politically interested youth has yet to be researched. This study seeks to fill in the gaps and broaden our understanding of the relationship between education and civic participation by comparing the links of vocational and academic education with civic outcomes, namely political interest and voting practices in two different educational contexts: England and Germany.

\section{Rationale for the comparative study}

Education takes many different forms even across Western Europe, encompassing systems of compulsory and post-compulsory education, vocational education and training (VET) and academic education. The educational contexts of Germany and England are two such examples of contrasting systems, which will enable us to understand more about the role of post-compulsory education in the formation of civic engagement.

Before introducing our theoretical framework, it is important to set out the major differences between the educational systems of these two countries which may lead to differences or similarities in civic engagement. First, the German education system is more stratified according to academic ability than the English system. In Germany, high academic ability pupils are streamed as early as the age of 10 in the Gymnasium, which is a more traditional academic route and enables school leavers to enter university ${ }^{i}$. In England, some degree of stratification exists in particular with wealthier or better-educated parents using the system to their advantage to gain access to the 'better' state schools (Ball, 2003). The A-level results in England, taken around the age of 18, are used by universities as entrance criteria. Since academic ability is associated with higher civic participation (Hillygus, 2005), it is important to account for the different forms of stratification of the education systems to partially deal with academic ability bias.

Secondly, there are important intergenerational mechanisms which affect both parental selection of education for children (Fleury \& Gilles, 2015) and parental influence on children's future civic engagement (Gidengil, Wass \& Valaste, 2016). In Germany, the educational background of parents is a strong predictor of the school their children attend. University graduates are more likely to put their children into the Gymnasium, where the Abitur examination is taken at age 19 (approximately), which is a precondition for entering University (Solga \& Dombrowski, 2009). In England, there are also large gaps in participation in higher education as measured by socioeconomic disadvantage (Chowdry, Crawford, Dearden, Goodman \& Vignoles, 2013). It is likely therefore that family background is a strong predictor of educational outcomes and potentially of young people's civic engagement in both England and Germany.

Finally, there are important differences between the vocational education and training systems of the two countries which are worth highlighting (see Bosch, 2015; Brockmann, Clarke \& Winch, 2009 for further discussion). The renowned dual-system of Germany is an example of Berufliche Bildung, with strong links between education and industry and clear paths for young apprentices to follow to gain accreditation in their particular field (Rauner, 2006). Vocational education in Germany is both valued and necessary for many occupations, having a broader focus in this respect than the English system and garnering more status as a result (Hillmert, 2002). The curriculum of the VET system in Germany is knowledge-based and designed to develop multidimensional competencies, from theory to practice, from civic education to personal development as opposed to the English system which concentrates on a narrow set of skills without a focus on personal development (Brockmann et al. , 2009). Indeed in the early 1990s about two thirds of school leavers (including those with an Abitur) took up an apprenticeship (BIBB, n.d.).

In contrast, the English vocational system is a 'market of qualifications' (Rauner, 2006), where students gain accreditation via a complex array of courses. The system of vocational education and training in England has undergone myriad reforms in the past few decades, with apprenticeship 
schemes withdrawn and later reinstated and qualifications offered by a number of nongovernmental organisations with little in the way of coherence or standardisation. Primarily these changes have been driven by attempts to raise the status of vocational education and generate more 'parity of esteem' between vocational and academic education, but with little effect (Wolf, 2011). Critics have also suggested that reforms have been more about successive attempts to reduce youth unemployment than in improving the content and structure of vocational education and training (Shavit \& Müller, 2000).

\section{Civic participation and education: \\ theory and evidence}

While there is consensus that education benefits individuals and society, there has been much debate about how these benefits occur (OECD, 2007). Disciplines as diverse as economics, psychology and sociology have identified key channels through which engaging in education can impact on individuals: social capital, human capital and identity capital. These 'three capitals' have been developed into an integrated framework in relation to the wider benefits of education (Schuller, Preston, Hammond, Brassett-Grundy and Bynner, 2004) and are relevant to the formation of civic participation and engagement as follows.

Firstly, the educational context increases an individual's social capital by introducing them to new peer groups and developing relationships between students and with teachers (Glaeser, Ponzetto \& Shleifer, 2007). Recent research by Kawashima-Ginsberg and Levine (2014) indicates that young people who attend racially mixed high schools tend to be less politically engaged later in life. However, the authors suggest that schoolbased participation in social issues and mixing with peers who share common interests tend to be positively associated with political participation, in particular voting. Secondly, individuals acquire skills and knowledge, in particular civic knowledge (Hillygus, 2005) through the learning process, which can be applied to other areas of their lives, for example, engaging in their community or wider society (Schuller et al., 2004). This is known as human capital and the capabilities that a student gains through education make them more effective citizens, more able to solve problems (Mirowsky \& Ross, 2005), and make informed decisions
(Grossman, 2005), which enable them to participate more fully in civic society. Human capital also encompasses the qualifications that people achieve in their educational history, which can translate into economic and social capital, giving those individuals greater access to political processes (Bourdieu, 1986).

Finally, the learning process itself can bring about increased self-esteem and a sense of identity (identity capital), which can create greater social cohesion (Côté, 2005). Identity capital refers to a sense of identity that not only accompanies learning, but is 'inseparable' from it, particularly in an apprenticeship setting where students 'become' a metier as well as learn it (Lave \& Wenger, 1991). In this regard researchers found that vocational trainees became included or excluded by the extent to which "they orientate themselves to a vocational habitus" (Colley, James, Diment \& Tedder, 2003; p.293). Linked to the concept of identity capital is Erikson's psychosocial moratorium referring to a period of time in which late adolescents/emerging adults can work out their identity (Erikson, 1956). The period of time that a student spends at university for example, can provide such an opportunity. However, being engaged in a low status role in the labour market might hinder the process (Schwartz, Côté \& Arnett, 2005).

In general terms, there is evidence of similarities between the countries in terms of trends in civic engagement. In Germany, notable differences were found between the younger and older generations, with younger people expressing much lower levels of interest than older members of society. A similar gap was found with regard to participating in elections (Weßels, 2008). Likewise research in the UK has shown that older people were more politically interested than the under $35 \mathrm{~s}$ at each educational level (Ogg, 2006). There are also withingeneration differences (Keating, Green and Janmaat, 2015), in terms of class and gender: women were less likely to be interested in politics than men and two thirds of people in higher social classes expressed an interest in politics compared with less than a fifth of those in the lower classes (Grenier and Wright, 2006).

With regard to the evidence on the relationship between education and civic participation, higher levels of education in the UK have been linked to greater levels of interest in politics (Brennan et al., 2013; OECD, 2010; Ogg, 2006). Siedler (2010) found 
no positive associations of education on political interest in Germany, whereas the Autorengruppe Bildungsberichterstattung (2014) describes profound differences between people with a university degree and those with no further education with regard to both political interest and voting. The 2014 edition of Education at a Glance reported that a third of people in Germany with tertiary education felt they had a say in government, compared to $13 \%$ who completed up to grade 10 (around age 16) of secondary schooling. In the UK, the figures were $42 \%$ and $22 \%$ respectively (OECD, 2014). In 2012, the OECD cited a 50\% 'voting gap' between the proportions of tertiary educated people aged 25-34 in Germany who said they would vote and those who completed up to grade 10 of secondary education. The gap in the UK was smaller but still sizeable at $32 \%$ (OECD, 2012).

The majority of research in this area has focussed on the role of years of study or highest academic qualification. Studies commissioned by the European Centre for the Development of Vocational Training (CEDEFOP) examined the role of VET for individuals, firms and nations. The outcome of one of such studies on the benefits of VET for adults aged 16 and over revealed that across Europe, positive increases in civic participation, as measured by higher proportion of individuals reporting membership of civic organisations, was greater for adults who had undertaken vocational education and training than for those who were not in education (Sabates et al., 2010). However, the authors found that when the same analysis was undertaken at the country level, results showed that these benefits of VET on civic participation were found only in Southern European countries (Greece, Italy, Spain and Portugal) as well as in Austria and Sweden, but not in Germany or the UK. A further limitation of the empirical literature is the fact that a longitudinal dimension is lacking from the research to date, as is any controlling for confounding factors except income and gender when undertaking comparative research across countries. Our analysis addresses these gaps, by using longitudinal panel data, differentiating by type of post-compulsory education and controlling for a range of background measures.

From theory, we propose that education has the potential to increase an individual's capital (social, human and identity), which may result in increased social status, which in turn enables individuals to access and engage with political processes in society (OECD, 2010). However, the impact of education on people's capitals is tempered by factors within the system of education in which it takes place (Shavit \& Müller, 1998). In a crossEuropean study, the beneficial effects of vocational education and training were shown to be dependent on the national context; civic participation outcomes were likely to be enhanced by vocational education in countries where these were rewarded or acted as a safety net for the unemployed (Sabates, Salter \& Obolenskaya, 2012). Likewise, greater civic engagement and a stronger interest in politics was discovered among German vocational trainees, (Fouad \& Bynner, 2008; Bynner, 2011) than their English counterparts.

A comparative analysis of outcomes within the differing national contexts of England and Germany enables us to propose hypotheses about the role of education in building social capital, which can be realised through civic participation and engagement. Against the outlined theoretical background, it can be hypothesised that an apprenticeship model such as the German dualsystem provides a better milieu for increasing identity capital than the British model of vocational education and training, which in comparison has been more piecemeal. Despite the higher status of vocational education and training in Germany, in both countries, an accredited academic qualification still confers a greater amount of social capital, in terms of social status and access to political institutions (Feinstein, Hammond, Woods, Preston \& Bynner, 2003). On this basis we would expect improved outcomes for civic participation for all types of education, but within this we would expect more nuanced results: an academic education will be associated with higher levels of political interest in both countries, but vocational education and training will be associated with higher levels of civic engagement in Germany than in England.

Thus our main research questions are:

1. Does the type of post-compulsory education (that is academic education, vocational training or a combination of both) influence civic outcomes later in the life course? 
2. Do different national educational systems result in different outcomes? Specifically, does academic or vocational education result in different outcomes with regard to political interest or engagement in England and Germany?

Hence, while the aim of the study is to investigate the role of both vocational and academic education on civic outcomes, key to its success is the comparative nature of the analysis. The selection of these two countries, and their differing educational context, allow us to understand whether the post-compulsory education context is important in developing an interest in politics.

\section{Data and variables}

We used the British Household Panel Survey (BHPS) and the German Socio-Economic Panel (SOEP) survey to study the benefits of different post-compulsory educational trajectories on civic participation compared with those who left education after completing compulsory schooling. The BHPS started in 1991, initially interviewing 10,264 individuals in 5,511 households in Great Britain (Taylor, Brice, Buck \& Prentice-Lane, 2010). The SOEP commenced in 1984 with an initial sample of 12,245 individuals in 5,921 households (Kroh \& Spieß, 2008) in both East and West Germany. The main reason for selecting these datasets was their comparability in terms of structure, time period and measures. Additionally, both datasets are rich in information on educational qualifications enabling us to construct detailed educational trajectories for all individuals. The BHPS started in 1991 and we chose the same reference year for Germany, thus confining the observations from Germany to the post re-unification years.

In order to obtain the cohort of young people with the longest history in the datasets, we included young people aged between 16 and 21 years old in 1991 in England and between 17 and 21 in Germanyii, following them annually until 2010, when they were aged between 35-40 years old. This enables us to look at the original sample members of the datasets, that is, those that were interviewed in the initial wave, with the advantage that they show less attrition than their peers who entered the survey in subsequent waves. The BHPS sample was restricted to include young people who studied in the English education system to make neater cross-country comparisons between England and Germany. In order to minimise the amount of missing data, the sample for analysis excluded people who dropped out of the survey before they reached twenty years of age. Our final sample for estimation purposes comprised 732 and 878 young people in England and Germany, respectively.

\section{Explanatory variable: Educational trajectories}

The explanatory variable in the model is the type of education that the young people completed during their transition to adulthood. The longitudinal nature of the dataset enabled us to construct educational trajectories for the young people in each country using three steps. Firstly, we coded the annual information they gave regarding their post-compulsory educational qualifications as either academic or vocational following the International Standard Classification of Education so that qualifications in England and Germany were comparable. Secondly, we constructed educational trajectories for respondents in each country, taking into account the differences outlined earlier between the two systems in terms of compulsory school leaving age and in age of graduation. The compulsory school leaving age in England in the period under study was 16 , while in Germany it was 18. In Germany, before the Bologna Process came into force, the average age at graduation from university was 28 , while in the UK it was as early as 21 , with some degrees taking a few years more (OECD, 2002) ) $^{\mathrm{iii}}$. Consequently, the information used for constructing trajectories for the English cohort were between the ages of 16 and 25 and those for the German cohort between 17 and 28 years of age.

Within the age range between post-compulsory schooling and completion of higher education, educational qualifications achieved during a specific year were classified as either academic or vocational. In doing so, we encounter repeated episodes of either vocational or academic qualifications. The final step was to use this longitudinal data on educational qualifications to categorise the young people's educational trajectories into one of four types: academic only, vocational only, mixed (people who had achieved both academic and vocational education and training in any order) and no further education. Figure 1 shows the proportion of young people who comprised these categories in each country. 
Figure 1: Proportion of respondents in each educational category in England ( $n=732)$ and Germany ( $n=878)$

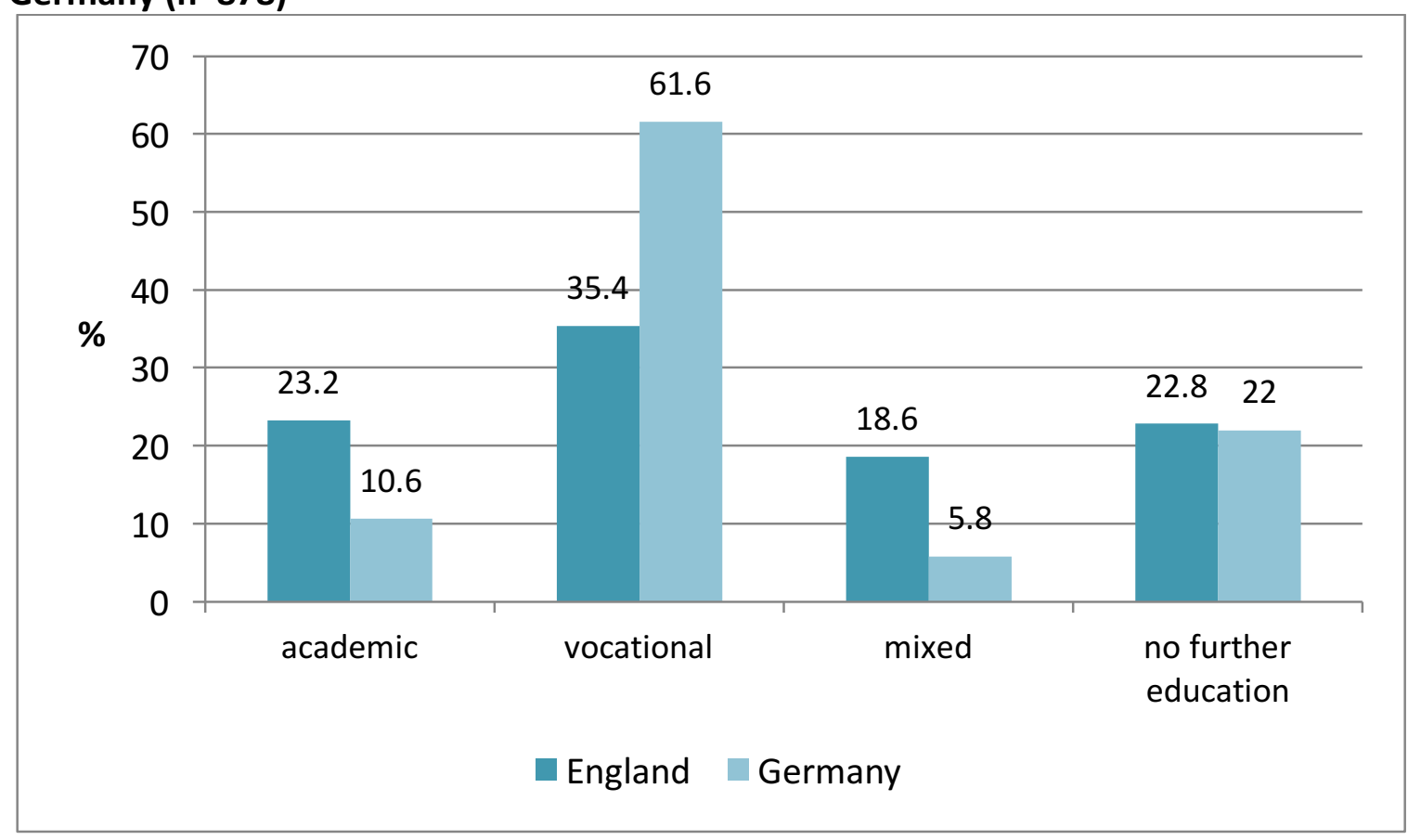

Figure 1 reveals already profound differences in the allocation of the educational categories between the two countries, thus reflecting the different educational systems. In the nineties, in England the proportion following the academic track was more than twice as high as in Germany; on the other hand the proportion with vocational training was much higher in Germany. In both samples, however, one in five respondents left school without following further education.

\section{Dependent variables: Interest in politics and voting}

In line with previous research civic engagement was operationalized by two measures of civic participation: political interest and voting.

Political interest was measured by the question 'how interested are you in politics?' with four possible responses from 'very interested' to 'not interested'. The responses were reduced to a threepoint scale in both datasets as the number of respondents in the category 'very interested' was too small. The outcome was measured at age 25 and age 35 to examine the immediate and longterm roles of education.

Voting was measured in the general election years in both countries (1997 and 2005 in England and 2005 and 2009 in Germany) with the questions: "did you vote in the last election?" for the BHPS, which captures actual voting behaviour earlier in the year, and "would you vote if there was an election on Sunday?" in the SOEP, which captures expectation to vote. Table 1 shows descriptive statistics for these outcome variables in Germany and England. Political interest is generally higher in England than in Germany; the proportion expressing fairly or very interested in politics is about ten per cent higher. The proportion of people who voted is about $16-18 \%$ higher in England than in Germany, however, since one survey measured intent to vote and the other actual voting behaviour, this difference may be due in part to the nature of the questions posed. 


\section{Table 1: Descriptive statistics of outcome variables measuring civic engagement in BHPS and SOEP (\%)}

Germany England

\begin{tabular}{|c|c|c|c|c|c|}
\hline Level of political interest & & Age 25 & Age 35 & Age 25 & Age 35 \\
\hline fairly or very interested & & 26 & 30 & 36 & 41 \\
\hline not very interested & & 60 & 53 & 34 & 30 \\
\hline not interested at all & & 14 & 17 & 30 & 29 \\
\hline Voting & & 2005 & 2009 & 1997 & 2005 \\
\hline Would you vote? (Germany) & Yes & 42 & 45 & n.a. & n.a. \\
\hline Did you vote? (England) & Yes & n.a. & n.a. & 58 & 63 \\
\hline
\end{tabular}

Source: SOEP \& BHPS.

\section{Controls: Background factors}

We introduced a number of socio-demographic factors into our models in order to see whether any possible statistical associations of post-compulsory education were driven by background factors occurring earlier in the life course. The sociodemographic variables included out of theoretical considerations and in line with previous research were parental education and parental occupational class and prior education (Plutzer, 2002). A small difference in the parental occupational class variable is that in Germany we used father's occupational class as the majority of mothers in the German sample had been housewives when occupational class was measured. Prior education enables us to capture prior ability to some degree (Hillygus, 2005), and it was measured in England by GCSE attainment (five or more GCSEs at grades A-C) and in Germany by whether or not students participated in Gymnasium. All regressions include gender as a factor to differentiate between differences in political interest and voting between young men and young women (Schoon, McCulloch, Joshi, Wiggins \& Bynner, 2001). Year of birth, coded as a set of dummy variables, was included as a control in all years since the sample spans six birth years, to control for any cohort effects.

\section{Analysis}

Three linear models were run: firstly, the outcomes at age 35 were regressed on postcompulsory education, controlling only for gender and birth year, to see whether there were any differences by type of education. The second model analysed the relationship of post-compulsory education on outcomes at age 35, with the inclusion of political interest at age 25 , to investigate if the relationship of education were visible at an earlier time point, again, controlling only for gender and birth year. Thirdly, the final model (see figure 2) was the same as model 2 with the addition of background controls, to see if these had any effect on the relationship between education and political interest. In addition, we tested for the significance of the indirect associations of further education on the outcome at age 35 via the outcome at age 25 using bootstrapped standard errors (Mackinnon, 2008). In all models, the post-compulsory education category of 'no further education' was the reference category; that is, each model compared the outcomes for those who had continued in any of the three routes through post-compulsory education with those who had left the education system. 
Figure 2: Model 3

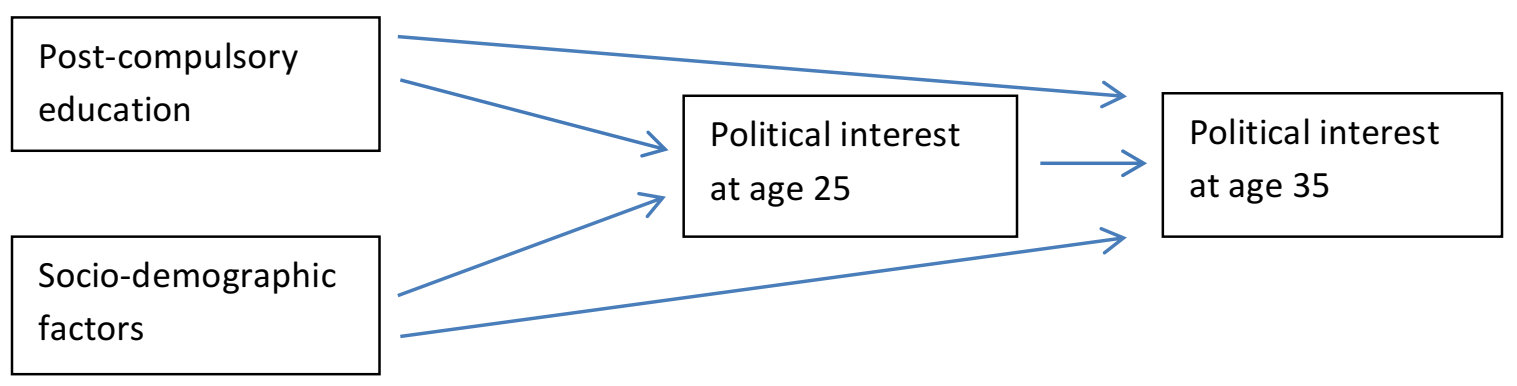

All analyses were run in MPlus (Muthén \& Muthén, 1998-2015). In order to deal with missing data in the two datasets, multiple imputation was used. One advantage of multiple imputation is that we can include more variables in the model to derive imputed values than are included in our substantive models, and therefore include variables that cause missingness but are not of substantive interest. For instance, in the BHPS, household income and scores on the general health questionnaire (a measure of psychological wellbeing) between ages 21 to 35 were included as potential predictors of missingness. We imputed twenty datasets as this is deemed a sufficient number (Enders, 2010; Schafer \& Graham, 2002). Both political interest and voting were treated as categorical dependent variables and models used a robust weighted least squares estimator, with bootstrapped standard errors based on 2000 bootstrapped samples.

\section{Results}

\section{Political interest}

In England, model 1 in table 2 shows that individuals who gained academic qualifications or a mixture of academic and vocational qualifications reported higher levels of interest in politics at age 35 than their peers who left school at 16 without qualifications. Model 2 shows, however, that academic education and mixed education are associated with greater political interest at age 25 and that direct effects of type of education on political interest at 35 are no longer significant. Model 3 shows that with the introduction of background controls, individuals with academic education and a mixture of academic and vocational qualifications remain statistically significantly associated with higher levels of political interest at 25 and indirectly at 35 than individuals who left school at 16 without qualifications. In none of the models shown in table 2 do we find statistical differences in the levels of political interest between individuals who achieved vocational qualifications and individuals who left school at age 16 . Finally, table 2 , model 3 shows that men are more likely to be interested in politics at age 35 and age 25 compared with women and that parental education and educational attainment at age 16 were statistically significant predictors of political interest at age 35, but not at age 25 . 
Table 2: Linear panel results for effects of post-compulsory education on political interest in England

\begin{tabular}{lccc} 
& Model 1 & Model 2 & Model 3 \\
\hline Effect on political interest at 35 & & & \\
\hline Academic & $0.606^{* *}$ & 0.117 & -0.112 \\
Vocational & -0.067 & -0.087 & -0.113 \\
Mixed & $0.609^{* *}$ & 0.314 & 0.148 \\
Gender = male & $0.323^{* *}$ & $0.469^{* *}$ & $0.474^{* *}$ \\
Political interest at 25 & & $0.553^{* *}$ & $0.559^{* *}$ \\
Parental education & & & $0.288^{*}$ \\
Parental social class & & & -0.165 \\
5+ GCSEs A-C & & & $0.371^{*}$ \\
Year controls & Yes & & Yes \\
\hline Mediated effects via political interest at 25 & & & \\
\hline Academic & & & $0.441^{* *}$ \\
Vocational & & & 0.022 \\
Mixed & & & $0.266^{*}$ \\
\hline Effect on political interest at 25 & & & \\
\hline Academic & & $0.886^{* *}$ & $0.716^{* *}$ \\
Vocational & & 0.039 & 0.039 \\
Mixed & & $0.531^{*}$ & $0.428^{*}$ \\
Gender=Male & & $0.277^{*}$ & $0.282^{*}$ \\
Parental education & & & -0.134 \\
Parental social class & & & 0.223 \\
5+ GCSEs A-C & & & 0.238 \\
Year controls & & & Yes \\
\hline Source: BHPS. Notes: Asterisk *** represent statistical & & \\
\hline
\end{tabular}

Source: BHPS. Notes: Asterisks * ${ }^{* *}$ represent statistical significance at $5 \%, 1 \%$ respectively.

In Germany, model 1 in table 3 shows that individuals at age 35 with an academic education reported a greater interest in politics than those with no further education. Similarly, individuals with mixed educational qualifications reported greater interest in politics at age 35 compared with individuals with no further educational qualifications. Model 2 shows that there is a relationship between individuals with academic and mixed qualifications and higher levels of political interest at age 25, but there is also a direct effect of academic qualifications on political interest at age 35. Vocational trainees were not more likely to be interested in politics at age 25 than those who did not have further educational qualifications. Model 3 in table 3 shows that with the inclusion of background factors having an academic education and having mixed educational qualifications still have direct associations on levels of political interest at age 25 and indirectly with levels of political interest at age 35. In Germany, we also find that men are more likely to be politically interested at age 35 and at age 25 than women and that parental education and achievement of a Gymnasium are statistically significantly associated with political interest at age 25 only. 
Table 3: Linear panel results for effects of post-compulsory education on political interest in Germany

\begin{tabular}{|c|c|c|c|}
\hline & Model 1 & Model 2 & Model 3 \\
\hline \multicolumn{4}{|c|}{ Effect on political interest at 35} \\
\hline Academic & $0.663 * *$ & $0.294^{*}$ & $0.254^{*}$ \\
\hline Vocational & 0.011 & -0.024 & -0.039 \\
\hline Mixed & $0.387^{*}$ & 0.036 & -0.008 \\
\hline Gender $=$ male & $0.398 * *$ & $0.221^{*}$ & $0.227^{* *}$ \\
\hline Political interest at 25 & & $0.507 * *$ & $0.498 * *$ \\
\hline Parental education & & & -0.008 \\
\hline Parental social class & & & 0.074 \\
\hline Gymnasium & & & -0.013 \\
\hline Year controls & Yes & Yes & Yes \\
\hline \multicolumn{4}{|c|}{ Mediated effects via political interest at 25} \\
\hline Academic & & & $0.302 * *$ \\
\hline Vocational & & & 0.002 \\
\hline Mixed & & & $0.206 * *$ \\
\hline \multicolumn{4}{|c|}{ Effect on political interest at 25} \\
\hline Academic & & $0.727 * *$ & $0.570 * *$ \\
\hline Vocational & & 0.070 & 0.003 \\
\hline Mixed & & $0.694 * *$ & $0.520 * *$ \\
\hline Gender=Male & & $0.350 * *$ & $0.345^{* *}$ \\
\hline Parental education & & & $0.132^{*}$ \\
\hline Parental social class & & & 0.095 \\
\hline Gymnasium & & & $0.495^{* *}$ \\
\hline Year controls & Yes & Yes & Yes \\
\hline
\end{tabular}

Source: SOEP. Notes: Asterisks * , ** represent statistical significance at $5 \%, 1 \%$ respectively.

In sum, there are similarities between the two countries: in both England and Germany, people who have an academic or mixed trajectory were more interested in politics than their peers who left education, while vocational trainees had similar levels of interest to their peers who have no further education. Additionally, in both countries, prior educational achievement in the form of GCSE attainment in England and attending Gymnasium in Germany is predictive of higher levels of political interest, although this is apparent earlier in adulthood, at age 25 in England, and later, at around age 35 in Germany. In both countries men reported, on average, higher levels of political interest than women.

\section{Voting}

Table 4 shows results for the likelihood of voting in the 2005 elections in England. Model 1 shows that individuals with academic or mixed qualifications were more likely to vote in the 2005 elections than individuals who left education at age 16. Individuals with vocational qualifications were not statistically different in their likelihood to vote in the 2005 elections from individuals who left education at age 16 . Similar results with respect to educational attainment and likelihood to vote in the 1997 elections were found in model 2, and that educational attainment did not have a direct effect on voting in 2005 once voting in 1997 was taken into account. In model 3, with the inclusion of 
background factors, we found that the statistical associations between education and likelihood of voting in the 1997 or 2005 elections were mostly conditioned out, and only a positive association between having mixed education and voting in 1997 relative to having no further education after the age of 16 remained statistically significant. We found that the inclusion of previous voting behaviour fully mediated the association between educational qualifications and voting in 2005 whereas the inclusion of prior educational attainment, achieving five or more A-Cs at GCSE, conditioned out the association between the attainment of academic qualifications and voting in the 1997 elections

Table 4: Linear panel results for effects of post-compulsory education on voting in England

\begin{tabular}{|c|c|c|c|}
\hline & Model 1 & Model 2 & Model 3 \\
\hline \multicolumn{4}{|c|}{ Effect on voting in 2005} \\
\hline Academic & $0.420^{*}$ & 0.128 & -0.099 \\
\hline Vocational & 0.007 & -0.070 & -0.083 \\
\hline Mixed & $0.539 * *$ & 0.235 & 0.079 \\
\hline Gender $=$ male & -0.228 & -0.145 & -0.130 \\
\hline Voting in 1997 & & $0.574 * *$ & $0.555^{* *}$ \\
\hline Parental education & & & 0.006 \\
\hline Parental social class & & & 0.015 \\
\hline $5+$ GCSEs A-C & & & $0.340 *$ \\
\hline Year controls & Yes & Yes & Yes \\
\hline \multicolumn{4}{|c|}{ Mediated effects via voting in 1997} \\
\hline Academic & & & 0.138 \\
\hline Vocational & & & 0.053 \\
\hline Mixed & & & 0.198 \\
\hline \multicolumn{4}{|c|}{ Effect on voting in 1997} \\
\hline Academic & & $0.509 * *$ & 0.232 \\
\hline Vocational & & 0.134 & 0.089 \\
\hline Mixed & & $0.531 * *$ & $0.333^{*}$ \\
\hline Gender=Male & & -0.145 & -0.134 \\
\hline Parental education & & & 0.016 \\
\hline Parental social class & & & 0.086 \\
\hline $5+$ GCSEs A-C & & & $0.295^{*}$ \\
\hline Year controls & Yes & Yes & Yes \\
\hline
\end{tabular}

Source: BHPS. Notes: Asterisks *, ${ }^{* *}$ represent statistical significance at $5 \%, 1 \%$ respectively.

Finally, table 5 presents results for likelihood of voting in Germany. Model 1 shows that individuals with academic or mixed qualifications were more likely to vote in 2009 than their peers who had left education. We again find that vocational trainees were similar in their likelihood to vote in 2009 compared with individuals who had left education. When voting in 2005 is added into the model, we continue to find a statistical association between academic or mixed qualifications and likelihood to vote in 2009 relative to individuals without postcompulsory qualifications (model 2 , table 5). But only individuals with academic qualifications were more likely to vote in 2005 compared with individuals who had left education. Finally, when we added background factors, model 3 shows a direct 
association between achievement of academic qualifications and mixed qualifications with likelihood to vote in 2009, relative to no educational qualifications; a direct association between achievement of academic qualifications with likelihood to vote in 2005 , relative to no educational qualifications; and an indirect association of achievement of academic qualifications and likelihood to vote in 2009. Attending Gymnasium was significantly associated with likelihood to vote in 2009 and 2005 whereas parental education was significantly associated with likelihood to vote in 2005 .

In the case of voting therefore, there are differences between the two countries. While post- compulsory education had limited associations with individuals' voting habits in England, academic or mixed trajectories were associated with a greater likelihood of voting in Germany. In both countries, vocational trainees exhibited similar voting practices to their contemporaries who had no further education. As with political interest, prior educational attainment had a positive association on voting habits early and later in adulthood in both England and Germany. In neither country did we find the parameter for gender to be statistically significant, which indicates that there are no differences in likelihood to vote between men and women in either England or Germany.

Table 5: Linear panel results for effects of post-compulsory education on voting in Germany

\begin{tabular}{|c|c|c|c|}
\hline & Model 1 & Model 2 & Model 3 \\
\hline \multicolumn{4}{|c|}{ Effect on voting in 2009} \\
\hline Academic & $0.896 * *$ & $0.450^{*}$ & $0.519 *$ \\
\hline Vocational & 0.057 & 0.063 & 0.047 \\
\hline Mixed & $0.841^{*}$ & $0.635^{*}$ & $0.707^{*}$ \\
\hline Gender $=$ male & -0.058 & 0.012 & 0.024 \\
\hline Voting in 2005 & & $0.552 * *$ & $0.547 * *$ \\
\hline Parental education & & & 0.034 \\
\hline Parental social class & & & -0.108 \\
\hline Gymnasium & & & $0.487^{*}$ \\
\hline Year controls & Yes & Yes & Yes \\
\hline \multicolumn{4}{|c|}{ Mediated effects via voting in 2005} \\
\hline Academic & & & $0.345^{*}$ \\
\hline Vocational & & & -0.120 \\
\hline Mixed & & & 0.051 \\
\hline \multicolumn{4}{|c|}{ Effect on voting in 2005} \\
\hline Academic & & $0.704 * *$ & $0.571^{*}$ \\
\hline Vocational & & -0.107 & -0.196 \\
\hline Mixed & & 0.220 & 0.088 \\
\hline Gender=Male & & -0.200 & -0.178 \\
\hline Parental education & & & $0.323 * *$ \\
\hline Parental social class & & & -0.157 \\
\hline Gymnasium & & & $0.475^{* *}$ \\
\hline Year controls & Yes & Yes & Yes \\
\hline
\end{tabular}

Source: SOEP. Notes: Asterisks * ** represent statistical significance at 5\%, 1\% respectively. 


\section{Discussion and conclusions}

Our research set out to investigate whether the type of post-compulsory education (that is either academic education or vocational training) followed by young people influenced their civic outcomes later in the life course and whether these associations differed in different educational systems. The results of our analyses show that the type of post-compulsory education does matter in terms of people's civic outcomes in adulthood. In both countries, people who followed an academic or mixed trajectory through post-compulsory education were more interested in politics and more likely to vote than their peers who had left education.

We hypothesised that both types of youth education would increase civic engagement through the development of the three capitals in the learning process and that the dual system of VET in Germany was more likely to have an effect on civic participation than VET in England. Our analysis instead found that vocational education does not increase young people's interest in politics or likelihood of voting compared to those who only complete compulsory education. While this was half-expected in the English context, it was an unexpected result for the dual-system of Germany.

While cross-sectional studies have repeatedly found associations between increased levels of education and increased levels of political interest, such studies do not take a longitudinal perspective and thus are unable to investigate the role of education in affecting civic outcomes at different points in life as well as the role of individual and family background factors in conditioning out the relationship of education to civic outcomes. We find that much of the initial association of postcompulsory education on civic outcomes later in life is explained by either the direct or indirect relationship of education on civic outcomes earlier in life. Gender impacts on political interest (men reported, on average, higher levels of political interest than women) but does not influence the likelihood to vote in both countries. The inclusion of family background variables, as well as previous educational attainment, contributes to conditioning out some of the differences between the attainment of post-compulsory academic qualification and greater civic participation. Nonetheless, these factors are not sufficient to condition out the potential academic ability bias, that is, academic ability simultaneously affecting educational attainment and political participation (Hillygus, 2005).

Our theoretical model aids in anchoring our results based on the hypothesis proposed. First, we expected to find an association between vocational education and civic participation in Germany due to the potential benefits of the dual system in terms of identity capital and thus increased civic participation. The fact that those who pursue vocational education and training in both countries are no more politically interested than those who do not gain post-compulsory qualifications questions to what extent this is due to the nature of individuals undertaking these qualifications as much as to the content of such qualifications. Despite the differences outlined earlier in the paper between the two educational systems, there are clear selection mechanisms in both countries, where parental background and parental education are highly predictive of the route that young people pursue in post-compulsory education. This raises the question of whether the kind of vocational education and training provision can readdress the potential consequences that socioeconomic disadvantage has on lack of civic and political engagement.

Secondly, our consistent results on the positive associations between the attainment of academic qualifications and civic engagement in both countries could be partially explained by the benefits of education due to increased skills and knowledge, in particular civic knowledge, which is more likely to be provided in academic environments. We acknowledge the limitation that it is not possible to ascertain from the results the specific content of academic provision, which is the main contributor to the level of political interest of those taking that route.

A further limitation is our inability to deal with bias due to omitted factors since we did not have the relevant data on unobservable variables such as social and cognitive skills or personality traits which are associated with educational attainment and with civic participation. The nature of our study, however, was not intended to measure causality, but to propose direction of associations and estimation of parameters using structural equations. A lack of data on civic interest at an earlier time point, such as at age 16, precluded us from seeing if there was an effect of pursuing 
vocational education and training which we were not able to capture in the current study.

The fact that vocational education was not associated with civic outcomes in two different environments but academic qualifications or a mixture of academic and vocational qualifications were associated with these outcomes in both countries therefore suggests two possibilities: either there is a lack of civic interest in the type of people pursuing vocational education which vocational education and training does not redress or that vocational education and training does not currently promote such interest, in either country. The inclusion of citizenship education at schoollevel and within vocational education and training in both countries may increase civic participation and interest, and as a result foster more democratic and cohesive societies. Nonetheless, further research is required to understand how the educational experience can enhance a more politically sensitive and civically engaged society.

\section{Acknowledgements}

This research was funded by the Economic and Social Research Council under grant ES/J021326/1.

\section{References}

Aristotle translated by Everson, S. (1996). The Politics and the Constitution of Athens. Cambridge, UK: Cambridge University Press.

Autorengruppe Bildungsberichterstattung (2014). Bildung in Deutschland 2014. Ein indikatorengestützter Bericht mit einer Analyse zur Bildung von Menschen mit Behinderungen. Bielefeld: Bertelsmann Verlag.

Ball, S.J. (2003). Class Strategies and the Educational Market: the middle classes and social advantage. London: Routledgefalmer. https://doi.org/10.4324/9780203218952

BIBB (n.d). Datenbank Auszubildende" des Bundesinstituts für Berufsbildung auf Basis der Daten der Berufsbildungsstatistik der statistischen Ämter des Bundes und der Länder (Erhebung zum 31. Dezember), Berichtsjahre 1993 bis 2010, und Bevölkerungsfortschreibung des Statistischen Bundesamtes, Berichtsjahre 1993 bis 2010. Absolutwerte aus Datenschutzgründen jeweils auf ein Vielfaches von 3 gerundet. Berechnungen des Bundesinstituts für Berufsbildung

Bosch, G. (2015). Different national skill systems. In K. Mayhew, C. Warhust (Eds.), Oxford Handbook of Skills and Training. Oxford: Oxford University Press (in press).

Bourdieu, P. (1986). The Forms of Capital. In Richardson, John G. (Ed.) Handbook of Theory and Research for the Sociology of Education. New York: Greenwood.

Brennan J., Durazzi, N. \& Sene, T. (2013). Things we know and don't know about the Wider Benefits of Higher Education: A review of the recent literature. BIS Research Paper Number 133. London: Department for Business Innovation and Skills.

Brockmann, M., Clarke, L \& Winch, C. (2009). Difficulties in recognising vocational skills and qualifications across Europe. Assessment in Education: Principles, Policy \& Practice 16, Special Issue: The Challenge of Cross-Border Qualifications Recognition, 97-109. https://doi.org/10.1080/09695940802704153

Bynner, J. (2011). Youth transitions and apprenticeships: A broader view of skill. In T. Dolphin \& T. Lanning (Eds.), Re-thinking apprenticeships (pp.17-28). London: IPPR.

Chowdry, H., Crawford, C., Dearden, L., Goodman, A. and Vignoles, A. (2013). Widening Participation in Higher Education: Analysis using Linked Administrative Data. Journal of the Royal Statistical Society: Series A (Statistics in Society), 176 (2), 431-457. https://doi.org/10.1111/j.1467-985X.2012.01043.x

Colley, H., James, D., Diment, K. \& Tedder, M. (2003). Learning as becoming in vocational education and training: class, gender and the role of vocational habitus. Journal of Vocational Education \& Training, 55(4), 471-498. https://doi.org/10.1080/13636820300200240 
Côté, J. E. (2005). Identity capital, social capital and the wider benefits of learning: generating resources facilitative of social cohesion. London Review of Education, 3(3), 221-237. https://doi.org/10.1080/14748460500372382

de Walque, D. (2007). Does education affect smoking behaviors? Evidence using the Vietnam draft as an instrument for college education. Journal of Health Economics, 26, 877-895. https://doi.org/10.1016/j.jhealeco.2006.12.005

Enders, C. K. (2010). Applied Missing Data Analysis. New York: Guilford Press.

Erikson, E.H. (1956). The problem of ego identity. Journal of the American Psychoanalytic Association, 4, 56121. https://doi.org/10.1177/000306515600400104

Feinstein, L., Hammond, C., Woods, L., Preston, J. \& Bynner, J. (2003) The Contribution of Adult Learning to Health and Social Capital, Wider Benefits of Learning Research Report No. 8. London: Centre for Research on the Wider Benefits of Learning, Institute of Education.

Fleury, N. \& Gilles, F. (2015). A meta-regression analysis on intergenerational transmission of education: publication bias and genuine empirical effect. Travail, Emploi et Politiques Publiques (TEPP) Working Paper 2015-02, Paris, France: TEPP.

Fouad, N. \& Bynner, J. (2008). Work Transitions. American Psychologist, 63(4), 241-251. https://doi.org/10.1037/0003-066X.63.4.241

Gidengil, E., Wass, H. \& Valaste, M. (2016). Political Socialization and Voting. The Parent-Child Link in Turnout. Political Research Quarterly, 69 (2), 373-383. https://doi.org/10.1177/1065912916640900

Glaeser, E.L., Ponzetto, G.A.M. \& Shleifer, A. (2007). Why does democracy need education? Journal of Economic Growth, 12, 77-99. https://doi.org/10.1007/s10887-007-9015-1

Grossman, M. (2005). Education and Non-market Outcomes. NBER Working Paper 11582. Cambridge, MA: National Bureau of Educational Research. https://doi.org/10.3386/w11582

Grenier, P. \& Wright, K. (2006). Social Capital in Britain: Exploring the Hall Paradox, Policy Studies, 27 (1), 2753. https://doi.org/10.1080/01442870500499900

Hillmert, S. (2002). Labour Market Integration and Institutions: An Anglo-German Comparison. Work Employment Society, 16 (4), 675-701. https://doi.org/10.1177/095001702321587424

Hillygus, S. (2005). The Missing Link: Exploring the relationship between higher education and political engagement. Political Behaviour, 27 (1), 25-47. https://doi.org/10.1007/s11109-005-3075-8

Kawashima-Ginsberg, K. \& Levine, P. (2014). Diversity in classroom: The relationship between deliberative and associative opportunities in schools and later electoral engagement. Analyses of Social Issues and Public Policy, 14 (1), 394-414. https://doi.org/10.1111/asap.12038

Keating, A., Green, A. \& Janmaat, G. (2015). Young Adults and Politics Today: disengaged and disaffected or engaged and enraged?: The latest findings from the Citizenship Education Longitudinal Study (CELS). Working Paper.

Kroh, M. \& Spieß, M. (2008). Documentation of Sample Sizes and Panel Attrition in the German Socio Economic Panel (SOEP) (1984 until 2007). DIW Berlin Data documentation No 39.

Lave, J. \& Wenger, E. (1991). Situated Learning. Cambridge: Cambridge University Press. https://doi.org/10.1017/CBO9780511815355

Lochner, L. (2011). Non-productive benefits of education: Crime, Health and Good Citizenship. NBER Working Paper 16722. Cambridge, MA: National Bureau of Economic Research.

Mackinnon, D.P. (2008). Introduction to statistical mediation analysis. New York: Erlbaum.

Mirowsky, J. \& Ross, C.E. (2005). Education, learned effectiveness and health. London Review of Education, 3 (3), 205-220. https://doi.org/10.1080/14748460500372366

Muthén, L.K. \& Muthén, B.O. (1998-2015). Mplus User's Guide. Seventh Edition. Los Angeles, CA: Muthén \& Muthén.

OECD (2002). Education at a Glance. Paris: OECD Publishing. https://doi.org/10.1787/eag-2002-en

OECD (2007). Understanding the Social Outcomes of Learning. Paris: OECD Publishing.

OECD (2010). What are the social outcomes of education? In OECD, Education at a Glance 2010: OECD Indicators. Paris: OECD Publishing. https://doi.org/10.1787/eag-2010-en

OECD (2012) Education at a Glance. Paris: OECD Publishing. 
OECD (2014) Education at a Glance. Paris: OECD Publishing.

Ogg, J. (2006). A Brief Profile of the New British Establishment. The Political Quarterly, 77 (1), 81-89. https://doi.org/10.1111/j.1467-923X.2006.00783.x

Plutzer, E. (2002). Becoming a habitual voter: inertia, resources, and growth in young adulthood. American Political Science Review, 96(1), 41-56. https://doi.org/10.1017/S0003055402004227

Prior, M. (2010). You've Either Got It or You Don't? The Stability of Political Interest over the Life Cycle. The Journal of Politics, 72(3), 747-766. https://doi.org/10.1017/S0022381610000149

Rauner, F. (2006). Berufliche Bildung-die europäische Perspektive. In Grollmann, P., Spöttl, G. \& Rauner, F. (eds) Europäisierung Beruflicher Bildung - eine Gestaltungsaufgabe. Hamburg: Lit Verlag, 127-153.

Sabates, R., Salter, E., Bromberg, T., Voss-Dahm, D., Obolenskaya, P. \& Bosch, G. (2010). Social Benefits of Vocational Education and Training for Individuals: Concepts, Contexts and Empirical Results. Thessaloniki, Greece: CEDEFOP.

Sabates, R., Salter, E. \& Obolenskaya, P. (2012). The social benefits of initial vocational education and training for individuals in Europe. Journal of Vocational Education \& Training, 64(3), 233-244. https://doi.org/10.1080/13636820.2012.691530

Salter, E., Kuemmerling, A., Bond, R. \& Sabates, R. (2015). Post-compulsory education: what are the benefits? A comparative study of the social outcomes of education in England and Germany. Brighton: Centre for International Education, University of Sussex.

Schafer, J.L. \& Graham, J.W. (2002) Missing data: our view of the state of the art. Psychological Methods, 7, 147-177. https://doi.org/10.1037/1082-989X.7.2.147

Schoon, I., McCulloch, A., Joshi, H., Wiggins, R. \& Bynner, J. (2001). Transitions from school to work in a changing social context. Young, 9 (1): 4-22. https://doi.org/10.1177/110330880100900102

Schuller, T., Preston, J., Hammond, C., Brassett-Grundy, A. \& Bynner, J. (2004). The Benefits of Learning: The impact of education on health, family life and social capital. London: RoutledgeFalmer.

Schwartz, S.J., Côté, J.E. \& Arnett, J.J. (2005). Identity and agency in emerging adulthood: Two developmental routes in the Individualization Process. Youth Society, 37 (2): 201-229. https://doi.org/10.1177/0044118X05275965

Shavit, Y. \& Müller, W. (1998). From School to Work: A Comparative Study of Educational Qualifications and Occupational Destinations. Oxford: Oxford University Press.

Shavit, Y. \& Müller, W. (2000). Vocational Secondary Education: Where diversion and where safety net? European Societies, 2 (1), 29-50. https://doi.org/10.1080/146166900360710

Siedler, T. (2010). Schooling and citizenship in a young democracy: evidence from post-war Germany. Scandinavian Journal of Economics, 112 (2), 315-338. https://doi.org/10.1111/j.14679442.2010.01604.x

Solga, H. \& Dombrowski, R. (2009). Soziale Ungleichheiten in schulischer und außer-schulischer Bildung. Arbeitspapier 171.

Taylor, M. F., Brice, J., Buck, N. \& Prentice-Lane, E. (2010) British Household Panel Survey User Manual Volume A: Introduction, Technical Report and Appendices. Colchester: University of Essex.

University of Essex. Institute for Social and Economic Research, British Household Panel Survey: Waves 1-18, 1991-2009 [computer file]. 7th Edition. Colchester, Essex: UK Data Archive [distributor], July 2010. SN: 5151.

Weßels, B. (2008). Politische Integration und politisches Engagement. In: Statistisches Bundesamt (Eds.), Datenreport 2008. Ein Sozialbericht für die Bundesrepublik Deutschland (pp. 363-369). Bonn: SFG Servicecenter Fachverlage.

Wolf, A. (2011) Review of Vocational Education - The Wolf Report. London: Department for Education. 


\section{Endnotes}

'As in Germany education is organized at a regional level, the transition from primary school to the Gymnasium is not standardized nationally. In some regions teachers' recommendation (based upon grades) is decisive, in others it is parental choice.

ii The SOEP is only conducted with adults aged 17 and above, so the German sample consists of 17-21 year olds in 1991 instead.

iii It should be noted that graduate students in Germany in the 1990s usually left university with a full master degree or its equivalent.

${ }^{\text {iv }}$ Models for voting remain unchanged if we include political interest at 25 as control instead of voting in the previous election. We opted for voting in previous election as this is an observed behaviour rather than an attitude. 